\title{
Release Pattern of Ammonical and Nitrate Nitrogen in Inceptisol by the Use of Different Organic Manures
}

\author{
Subhash Singh, Tamboli*, B. D. Sonu Kumar and C.R. Palwe \\ Division of Soil Science and Agricultural Chemistry, College of Agriculture, \\ Pune, Mahatma Phule Krishi Vidyapeeth, Rahuri-413 722, India \\ *Corresponding author
}

\section{Ke y w o r d s}

Nitrogen

mineralization,

$\mathrm{C} / \mathrm{N}$ ratio, $\mathrm{C} / \mathrm{P}$ ratio

Organic input

quality, Ammonia

oxidizing bacteria

Article Info

Accepted:

15 December 2019

Available Online:

20 January 2020

\section{ABSTRACT}

Nitrogen in manure occurs mainly in organic forms (e.g., proteins) and as ammonium (NH4+). Some composted manures contain small amounts of nitrate. Ammonium and nitrate are plant-available forms of $\mathrm{N}$, while organic $\mathrm{N}$ is not immediately plant-available. Before organic $\mathrm{N}$ can be taken up, however, it must first be converted to inorganic forms. This process, which is completed by soil microbes as a by-product of organic matter decomposition, is called mineralization. The mineralization rate is therefore the rate at which organic $\mathrm{N}$ is made plant available. In manure forage systems, mineralization accounts for much or most of crop needs. To calculate the $\mathrm{N}$ fertilizer value of manure and to construct crop $\mathrm{N}$ budgets, an estimate of the rate of mineralization is useful. An understanding of the mineralization rate concept can help improve manure management to meet crop $\mathrm{N}$ demands.However, proper management of organic manures requires a capacity to predict their effect of $\mathrm{N}$ dynamics in inceptisol and their availability to crops. The quality of organic material is reflected in the carbon $(\mathrm{C})$, nitrogen $(\mathrm{N})$ and $\mathrm{C} / \mathrm{N}$ ratio. These quality indicators are useful in predicting the $\mathrm{N}$ turnover and mineralization of organic residues. Generally, manures with low $\mathrm{C} / \mathrm{N}$ ratio (lesser than 10:1) result in greater $\mathrm{N}$ availability at the early stage of decomposition. Therefore it gives real benefits of applying these organic materials to soil.

\section{Introduction}

In recent past, there is a renewal interest on the use of organic resources in agricultural for maintaining soil organic matter, improving soil quality and supplying plant nutrient for sustainable crop production. The use of organic waste in the amendment of agricultural soils can be beneficial for crops, and the same time, provide an efficient and cost effective method for its disposal. The organic fraction of manure can significantly increase soil aggregation, infiltration, microbial activity, structure, and water-holding capacity and can reduce soil compaction and erosion. Therefore, it gives real benefits of applying these organic materials to soil. The determination of $\mathrm{N}$ mineralization potential in soil after organic amendments allows the evaluation of $\mathrm{N}$ dynamics in the soil and its true effectiveness in economic and ecological effect (Pedra et al., 2011).

The incorporation of organic manures into soil is considered a good management practices because it stimulates soil microbial activity and increases soil fertility through mineralization. Inceptisol are in medium range of organic matter which is the backbone for the sustainability of soil fertility and 
productivity. An improved understanding of the competing processes of $\mathrm{N}$ mineralization and $\mathrm{N}$ immobilization, along with their temporal dynamic's, may improve our ability to manage $\mathrm{N}$ cycling, increase Nitrogen use efficiency (NUE) by minimizing $\mathrm{N}$ losses whatever the form, and increase the sustainability of agricultural system that utilize typically applied organic $\mathrm{N}$ sources (Cabrera et al., 2005).

Stanford and Smith (1972) were establishing the $\mathrm{N}$ mineralization capacity through long term incubation procedures. Kinetics parameters in mineralization study can be potentially used to access the mineralization-immobilization process in soils under varying environmental and management conditions. Nitrogen-use efficiency can be enhanced through the understanding of $\mathrm{N}$ mineralization potential of different organic sources. The aim of present study was to determine and compare $\mathrm{N}$ mineralization rate, under laboratory condition amended with different organic residues in Inceptisol. The suitability of organic residues as a source of $\mathrm{N}$ depends to great extent on its mineralization of $\mathrm{N}$ in relation to crop demand.

\section{Materials and Methods}

The eight value added organic manures in $1 \mathrm{~kg}$ Inceptisol of Typic Haplustept family air dried 2 $\mathrm{mm}$ sieve soil were used for conducting experiment in plastic bowl with capacity of $1.5 \mathrm{~kg}$ at field capacity moisture regimes ( 0.33 bar), maintained by double distillery water throughout the incubation period in three replications under Completely Randomized Design. The organic manures sources were applied at the rate of 100 $\mathrm{mg} \mathrm{N} \mathrm{kg}^{-1}$ soil (Table 1) and treatment details are following:

\begin{tabular}{|l|l|l|}
\hline & Organic Manure & Source \\
\hline $\mathrm{T}_{1}$ & Farm Yard Manure (FYM) & $\begin{array}{l}\text { Agronomy Division College of } \\
\text { Agriculture }\end{array}$ \\
\hline $\mathrm{T}_{2}$ & Vermicompost & College of Agriculture \\
\hline $\mathrm{T}_{3}$ & Press Mud Cake & Vasant Dada Suger Institute \\
\hline $\mathrm{T}_{4}$ & Press Mud Compost & Vasant Dada Suger Institute \\
\hline $\mathrm{T}_{5}$ & Poultry Manure & $\begin{array}{l}\text { Animal Husbandry and Dairy } \\
\text { Science }\end{array}$ \\
\hline $\mathrm{T}_{6}$ & Coco-Pit Compost & College of Agriculture \\
\hline $\mathrm{T}_{7}$ & Urban Compost & Municipal corporation \\
\hline $\mathrm{T}_{8}$ & Spent Mushroom Compost & AICRP \\
\hline $\mathrm{T}_{9}$ & Soil (Control) & Agronomy Farm \\
\hline
\end{tabular}

Physico-chemical and Chemical properties of soil

Soil moisture at field capacity determined by Pressure plate membrane apparatus method (Richards, 1949), pH (1:2.5, Soil: water)

Potentiometry and EC (1:2.5,Soil:water) Conductometry method, Organic carbon by Wet oxidation as explain by Jackson, 1973), Calcium carbonate by Acid neutralization (Allison and

Moodie, 1965), Available N Alkaline permanganate (Subbiah and Asija, 1956), Available phosphorus $0.5 \mathrm{M} \mathrm{NaHCO} 3$ at $\mathrm{pH} 8.5$ ascorbic acid (Watanabe and Olsen, 1965), Available potassium by Neutral Normal $\mathrm{NH}_{4} \mathrm{OAc}$ (Knudsen et al.,1982), Micronutrient( $\mathrm{Mn}, \mathrm{Fe}, \mathrm{Cu}$, $\mathrm{Zn}$ ) by DTPA extractable method (Lindsay and Norvell, 1978) and $\mathrm{NH}_{4}-\mathrm{N}$ and $\mathrm{NO}_{3} \quad-\mathrm{N}$ determined with $2 M \mathrm{KCl}$ solution (1:10 sample: extratant ratio) by steam distillation in presence of $\mathrm{MgO}$ and Devardas alloy method respectively as explain by Keeney and Nelson (1982). The $5 \mathrm{~g}$ soil from each bowl was weighted for analysis of $\mathrm{NH}_{4}-\mathrm{N}$ and $\mathrm{NO}_{3}-\mathrm{N}$ at 15 days interval up to 90 days.

\section{Organic manure analysis}

The well decomposed organic manures samples were air dried under shed and adopting

appropriate standard methods such as Potentiometric for $\mathrm{pH}$ and Conductometry for EC(1:10 compost : water) as explain by Jackson (1973).Total nitrogen by Microkjeldahl method (Bremner and Mulvaney, 1982), Total phosphorus by Vandomolybdo -phosphate Yellow colour (Jackson, 1973), Total potassium by Flame photometer (Chapman and Pratt, 1961) while Organic carbon by Ignition method Gorsuch (1970).

\section{Result and Discussions}

\section{Characterization of organic manure}

The $\mathrm{pH}$ of different organic manures ranged from 5.0 to 8.6 with mean value of 7.47 . FYM recorded higher $\mathrm{pH}$ (8.6) while lower $\mathrm{pH}$ (5.0) in coco-pit compost. Electrical conductivity of poultry manure $\left(6.31 \mathrm{dS} \mathrm{m}^{-1}\right)$ was higher and lowest in press mud compost $\left(1.25 \mathrm{dS} \mathrm{m} \mathrm{m}^{-1}\right)$. The concentration of carbon in organic manures 
differed considerably ranging from $20.61 \%$ in spent mushroom compost to $33.94 \%$ in poultry manure with mean value $(26.80 \%)$. The $\mathrm{N}$ concentration in organic manures ranged from $0.71 \%$ in coco-pit compost to $3.09 \%$ in poultry manure. The concentration of total $\mathrm{P}$ in organic manures differed considerably ranging from $0.35 \%$ in coco-pit compost to $1.98 \%$ in press mud compost. Variation in total $\mathrm{K}$ concentration among the organic manures was small ranging from $0.33 \%$ in coco-pit compost to 0.94 in spent mushroom compost with mean value $(0.60 \%)$.

It was evident from the data following decreasing trend was obtained:

$\mathrm{N}$ concentration: poultry manure > urban compost $>$ vermicompost> press mud compost > FYM > spent mushroom compost $>$ press mud cake $>$ cocopit compost.

C/N ratio: coco-pit compost $>$ press mud cake $>$ FYM $>$ press mud compost > spent mushroom compost > urban compost >vermicompost> poultry manure.

$\mathrm{C} / \mathrm{P}$ ratio: coco-pit compost $>$ poultry manure $>$ urban compost $>$ FYM > spent mushroom compost $>$ vermicompost> press mud cake > press mud compost.

\section{Nitrogen mineralization}

The F.Y.M, vermicompost, press mud cake, press mud compost, poultry manures, coco-pit compost, urban compost and spent mushroom compost were incorporated in soil @ 100 mg of N kg-1 soil and incubated for total 90 days at field capacity moisture. The mineralization of $\mathrm{N}$ into NH4-N and NO3-N at different intervals was studied.

\section{Ammoniacal nitrogen (NH4- N)}

The soil amended with organic manures released significantly higher amount of NH4-N than that of soil alone. Amongst organic manures, poultry manure recorded highest amount of cumulative NH4-N (223.24 mg kg-1) this could be due to higher $\mathrm{N}$ content and narrower $\mathrm{C} / \mathrm{N}$ ratio. The next best treatment was urban compost followed by vermicompost. It was lowest in control (126.76 mg kg-1). The result indicated that the combined application of organic manures released higher amount of $\mathrm{N}$ than soil alone. This could be attributed to the rate of decomposition and amount of $\mathrm{N}$ mineralized varies with type of organic material added (Gupta and Tripathi, 1986).
The NH4-N release pattern from organic manures amended soil also recorded identical trend but magnitude of rate of mineralization followed the order; poultry manure $>$ urban compost $>$ vermicompost> press mud compost > FYM > spent mushroom compost > press mud cake > coco-pit compost > control.

\section{Nitrate nitrogen (NO3- N)}

The soil amended with organic manures released significantly higher amount of NO3- N than that amended with soil alone throughout incubation period. The rate of release NO3- $\mathrm{N}$ was slow in the beginning and released with a peak appearing at 45 days aerobic incubation.

There after NO3- $\mathrm{N}$ release decreased gradually beyond 45 days in all the soil amended with organic manure treatments. Generally poultry manure > urban compost >vermicompost> press mud compost $>$ FYM $>$ spent mushroom compost $>$ press mud cake > coco-pit compost > control was the decreasing order of organic manures on the basis of NO3- $\mathrm{N}$ values during mineralization. The cumulative NO3-N was more due to poultry manure (396.67 mg kg-1), urban compost (370.18 $\mathrm{mg} \mathrm{kg-1)}$ and vermicompost (353.15 mg kg-1) respectively. This could be due to higher $\mathrm{N}$ content and narrower $\mathrm{C} / \mathrm{N}$ ratio of poultry manure, urban compost and vermicompost respectively. It was lowest in control (208.11 mg kg-1). This result indicated that the combined application of organic manures released higher amount of NO3$\mathrm{N}$ than control or soil alone. This could be attributed to application of manures which on mineralization release inorganic $\mathrm{N}$ steadily.

\section{Nitrogen mineralization (NH4-N+NO3-N)}

The $\mathrm{N}$ mineralization values ranges between 90.18 and $126.13 \mathrm{mg} \mathrm{kg}-1$ at 0 and 45 days incubation thereafter it was declined at 90 days incubation (46.04 mg kg-1) in poultry manure while lowest was noticed in unamend soil or control and range was $40.36-73.15 \mathrm{mg} \mathrm{kg}-1$ at 45 days incubation and $22.07 \mathrm{mg} \mathrm{kg}-1$ at 90 days incubation. Amongst the organic manures poultry manure recorded highest rate of $\mathrm{N}$ mineralization (619.91 mg kg-1) the next best was urban compost (553.06 mg kg-1) followed by vermicompost (528.47 mg kg-1). This could be 
due to higher $\mathrm{N}$ content and narrower $\mathrm{C} / \mathrm{N}$ ratio of poultry manure, urban compost and vermicompost respectively. The ability of eight organic manures to release $\mathrm{N}$ was in the following order; poultry manure > urban compost >vermicompost> press mud compost $>$ FYM $>$ spent mushroom compost $>$ press mud cake > coco-pit compost. The lowest rate of $\mathrm{N}$ mineralization in coco-pit compost may be attributed to low $\mathrm{N}$ content and wider $\mathrm{C} / \mathrm{N}$ ratio was compared to the rest of organic manures. In general to summarize all the organic manures had almost reached the potential $\mathrm{N}$ mineralization incubation period 30 to 45 days indicating that organic manures may release $\mathrm{N}$ rapidly and provide sufficient $\mathrm{N}$ during amount of $\mathrm{N}$ mineralized by organic manures amended soil indicated that Total $\mathrm{N}$ content and $\mathrm{C} / \mathrm{N}$ ratio of organic manures were extremely important in predicting the amount of $\mathrm{N}$ mineralized.

The present study was conducted with view to evaluate the Characterization of organic manure, kinetics of $\mathrm{N}$ mineralization by using organic manures in Inceptisol and to find out the best fit mathematical model for assessing nitrogen mineralization in Inceptisol. The salient findings of investigation are summarized below:

The $\mathrm{pH}$ of ranged from 5.0 in coco-pit compost to 8.6 in FYM, EC $1.25 \mathrm{dS} \mathrm{m}^{-1}$ in press mud compost to $6.31 \mathrm{dS} \mathrm{m}^{-1}$ in poultry manure. The carbon in concentration in organic manure ranged from 20.61 per cent in spent mushroom compost to 33.94 per cent in poultry manure with mean value $(26.80 \%)$. The $\mathrm{N}$ concentration in organic manure ranged from 0.71 per cent in coco-pit compost to 3.09 per cent in poultry manure, $\mathrm{P}$ concentration 0.35 per cent in coco-pit compost to 1.98 per cent in press mud compost, $\mathrm{K}$ concentration 0.33 per cent in coco-pit compost to 0.94 per cent in spent mushroom compost. There was wide variation in $\mathrm{C} / \mathrm{N}$ and $\mathrm{C} / \mathrm{P}$ ratio of organic manures ratios. The $\mathrm{C} / \mathrm{N}$ ratio of organic manure varied inversely to their $\mathrm{N}$ concentration.

The $\mathrm{NH}_{4}-\mathrm{N}$ release pattern from organic manures amended soil also recorded identical increasing trend up to 45 days and thereafter decreasing trend was noticed. However, magnitude of rate of mineralization followed in the order: poultry manure $>$ urban compost $>$ vermicompost $>$ press mudcompost $>$ FYM $>$ spent mushroom compost $>$ press mud cake >coco-pit compost > control. The lowest cumulative release of $\mathrm{NH}_{4}-\mathrm{N}$ (142.54 $\mathrm{mg} \mathrm{N} \mathrm{Kg}{ }^{1}$ ) was noticed in coco-pit compost. The highest cumulative release of $\mathrm{NH}_{4}-\mathrm{N}(223.24 \mathrm{mg}$ $\mathrm{N} \mathrm{Kg}^{1}$ ) was observed in poultry manure. The rate of release of $\mathrm{NH}_{4}$-Nwas slow in the beginning and followed by sharp increase reaching, a peak at 45 days of incubation fallowed by gradual decline thereafter in all the organic manures amended treatments.

The poultry manure (396.67 $\mathrm{mg} \mathrm{kg}^{-1}$ ), urban compost (370.18 $\mathrm{mg} \mathrm{kg}^{-1}$ ) and vermicompost (353.15 $\mathrm{mg} \mathrm{kg}^{-1}$ ) observed the more cumulative $\mathrm{NO}_{3}-\mathrm{N}$ as compared with rest of the treatments. The soil amended with organic manures released significantly higher amount of $\mathrm{NO}_{3^{-}} \mathrm{N}$ than control treatment throughout the incubation period. The maximum, amount of $\mathrm{NO}_{3}-\mathrm{N}$ release was noticed at 45 days after incubation in all the sources of organic manures and control treatment. The decreasing order of release of nitrate nitrogen is poultry manure $>$ urban compost > vermicompost >press mud compost > FYM > spent mushroom compost >press mud cake $>$ coco-pit compost. Among the sources the cocopit recorded the lowestrelease of soil $\mathrm{NO}_{3}-\mathrm{N}$ throughout the incubation period but it was higher than control treatment.

Significantly the highest mineralized $\mathrm{NH}_{4}-\mathrm{N}+$ $\mathrm{NO}_{3}-\mathrm{N}$ was observed due to the application of poultry manure over all the sources of organic manure and control treatments throughout the incubation period. In general, the use of all the sources of organic manure significantly increased the release of $\mathrm{NH}_{4}-\mathrm{N}+\mathrm{NO}_{3}-\mathrm{N}$ as compared with control. The highest peak rate of $\mathrm{N}$ was attained at 45 days of incubation in all the treatments. Thereafter it gradually declined significantly at 90 days of incubation period. The application of poultry manure resulted in higher release rate of $\mathrm{NH}_{4}-\mathrm{N}+\mathrm{NO}_{3}-\mathrm{N}$ mineralization throughout incubation period. Amongst the organic manures poultry manure recorded the highest rate of $\mathrm{N}$ mineralization $\left(619.914 \mathrm{mg} \mathrm{kg}^{-1}\right)$ the next best was urban compost (553.06 $\mathrm{mg} \mathrm{kg}^{-1}$ ) fallowed by vermicompost $\left(547.28 \mathrm{mg} \mathrm{kg}^{-1}\right)$. In general, all the organic manures reached the potential $\mathrm{N}$ mineralization incubation period 35 to 45 days. 
Table.1 Chemical composition of Organic Manures

\begin{tabular}{|l|l|l|c|c|c|c|c|c|c|c|}
\hline Treatments & $\mathbf{p H}$ & $\begin{array}{c}\text { EC } \\
\mathbf{( 1 :}\end{array}$ & $\begin{array}{c}\text { Organic } \\
\text { carbon }\end{array}$ & $\begin{array}{c}\mathbf{( \% )} \\
\text { Total } \\
\text { nitrogen } \\
\mathbf{1 0}\end{array}$ & $\begin{array}{c}\text { Total } \\
\text { phosp } \\
\text { horus } \\
(\mathbf{\%})\end{array}$ & $\begin{array}{c}\text { Total } \\
\text { potassiu } \\
\mathbf{m}(\mathbf{\%})\end{array}$ & $\begin{array}{c}\text { C/N } \\
\text { Ratio }\end{array}$ & $\begin{array}{c}\text { C/N } \\
\text { Ratio }\end{array}$ & $\begin{array}{c}\text { Quantity of organic } \\
\text { manure (g) added } \\
\text { to maintain 100 mg } \\
\text { N kg-1 soil }\end{array}$ \\
\hline T1 & FYM & 8.6 & 2.29 & 22.46 & 1.12 & 0.70 & 0.41 & 20.05 & 32.08 & 8.93 \\
\hline T2 & Vermicompost & 7.5 & 2.6 & 24.52 & 1.82 & 1.20 & 0.75 & 13.47 & 20.43 & 5.48 \\
\hline T3 & Press mud cake & 7.4 & 1.77 & 30.67 & 1.07 & 1.80 & 0.43 & 28.66 & 17.03 & 9.34 \\
\hline T4 & Press mud compost & 8.4 & 1.25 & 24.95 & 1.30 & 1.98 & 0.61 & 19.19 & 12.60 & 7.66 \\
\hline T5 & Poultry manure & 7.8 & 6.31 & 33.94 & 3.09 & 0.68 & 0.57 & 10.98 & 49.91 & 3.23 \\
\hline T6 & Coco-pit compost & 5.0 & 3.64 & 25.35 & 0.71 & 0.35 & 0.33 & 35.70 & 72.43 & 14.00 \\
\hline T7 & Urban compost & 7.5 & 5.76 & 31.86 & 2.14 & 0.68 & 0.51 & 14.89 & 46.85 & 4.66 \\
\hline T8 & $\begin{array}{l}\text { Spent mushroom } \\
\text { compost }\end{array}$ & 7.6 & 5.23 & 20.61 & 1.11 & 0.75 & 0.94 & 18.57 & 27.48 & 9.04 \\
\hline
\end{tabular}

Table.2 Physico-chemical properties of soil

\begin{tabular}{|l|l|}
\hline \multicolumn{1}{|c|}{ Soil Properties } & Values \\
\hline Field capacity (\%) & 37.45 \\
\hline pH $(1: 2.5 ;$ soil: water) & 8.2 \\
\hline EC (dSm-1) & 0.58 \\
\hline Organic carbon (\%) & 0.38 \\
\hline CaCO3 equivalent (\%) & 13.25 \\
\hline Available nitrogen (kg ha-1) & 113 \\
\hline Available phosphorus (kg ha-1) & 20.3 \\
\hline Available potassium (kg ha-1) & 353 \\
\hline Ammonical nitrogen (mg kg-1) & 17.0 \\
\hline Nitrates nitrogen (mg kg-1) & 34.02 \\
\hline DTPA extractable $\mathrm{Zn} \mathrm{(mg} \mathrm{kg-1)}$ & 0.52 \\
\hline DTPA extractable Fe (mg kg-1) & 3.80 \\
\hline DTPA extractable $\mathrm{Mn}(\mathrm{mg} \mathrm{kg}-1)$ & 12.80 \\
\hline DTPA extractable Cu (mg kg-1) & 8.07 \\
\hline
\end{tabular}

Table.2 Effect of different organic manures on periodical NH4- N content of soil (mg kg-1)

\begin{tabular}{|c|c|c|c|c|c|c|c|c|c|}
\hline \multirow{2}{*}{\multicolumn{2}{|c|}{ Tre a $\mathbf{t}$ m e $\mathbf{t} s$}} & \multirow{2}{*}{$\begin{array}{l}\text { I n c } \\
0\end{array}$} & \multicolumn{2}{|c|}{ ub a t i on } & \multicolumn{2}{|c|}{ periods } & \multicolumn{2}{|c|}{$\left(\begin{array}{ll}\text { Da } & \text { y s }\end{array}\right)$} & \multirow[t]{2}{*}{ Cumulative total } \\
\hline & & & 15 & 30 & 45 & 60 & 75 & 90 & \\
\hline $\mathrm{T}_{1}$ & FYM & 18.29 & 22.70 & 30.27 & 36.58 & 23.33 & 17.03 & 10.09 & 158.29 \\
\hline $\mathrm{T}_{2}$ & Vermicompost & 21.44 & 24.59 & 32.79 & 40.99 & 24.59 & 18.92 & 11.98 & 175.32 \\
\hline $\mathrm{T}_{3}$ & Press mud cake & 17.03 & 22.07 & 29.01 & 35.95 & 23.33 & 15.14 & 8.20 & 150.72 \\
\hline $\mathrm{T}_{4}$ & Press mud compost & 20.18 & 23.96 & 32.79 & 38.47 & 24.59 & 17.66 & 10.72 & 168.38 \\
\hline $\mathrm{T}_{5}$ & Poultry manure & 32.16 & 37.21 & 41.62 & 49.82 & 27.12 & 20.81 & 14.50 & 223.24 \\
\hline $\mathrm{T}_{6}$ & Coco-pit compost & 15.77 & 20.20 & 29.01 & 34.05 & 22.07 & 13.87 & 7.57 & 142.54 \\
\hline $\mathrm{T}_{7}$ & Urban compost & 22.07 & 25.23 & 34.05 & 44.14 & 25.86 & 18.92 & 12.61 & 182.88 \\
\hline $\mathrm{T}_{8}$ & Spent mushroom compost & 17.03 & 22.07 & 30.27 & 35.95 & 23.33 & 15.77 & 9.46 & 153.87 \\
\hline $\mathrm{T}_{9}$ & Control & 14.50 & 18.92 & 25.86 & 27.75 & 20.81 & 12.61 & 6.31 & 126.76 \\
\hline \multicolumn{2}{|c|}{$\mathrm{SE} \pm$} & & 0.89 & 1.09 & 0.70 & 1.31 & 0.51 & 0.66 & 0.56 \\
\hline \multicolumn{2}{|c|}{ CD at $5 \%$} & & 2.73 & 3.28 & 2.66 & 4.47 & 1.57 & 2.19 & 1.87 \\
\hline
\end{tabular}




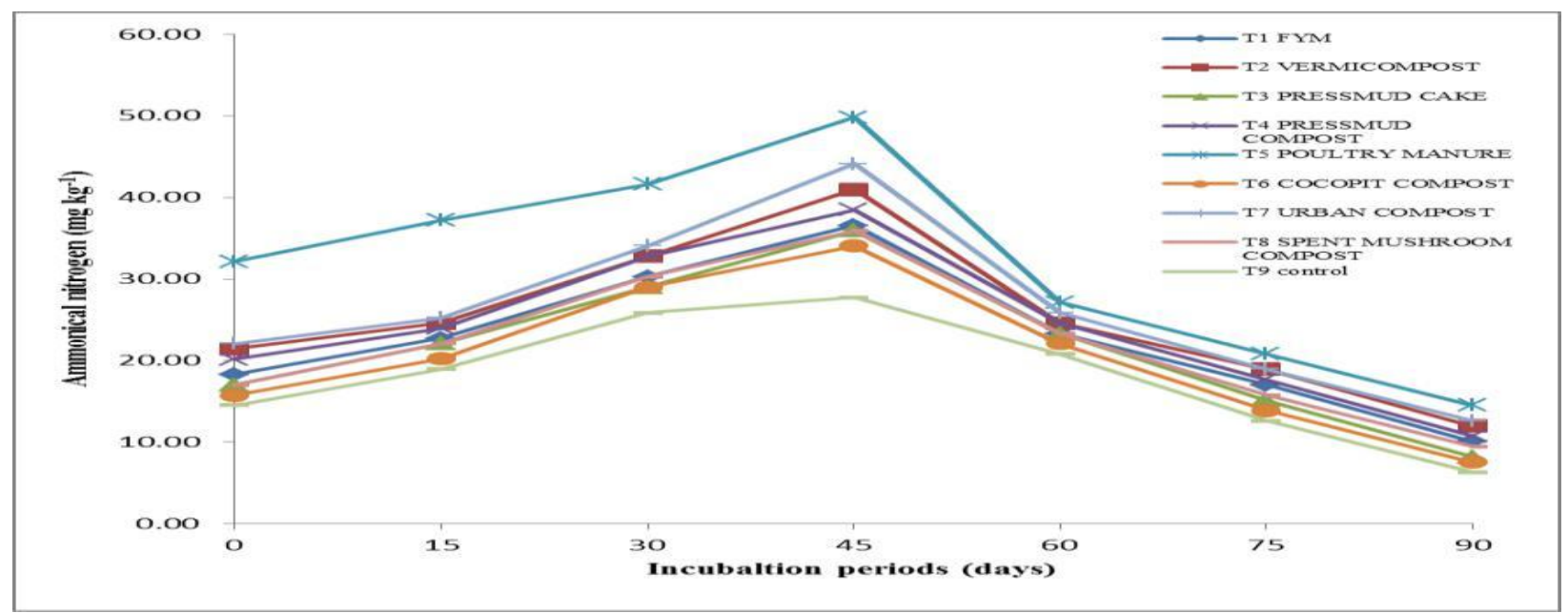

Fig.1 Periodical changes of $\mathrm{NH}_{4}-\mathrm{N}$ in soil from different organic manures for 90 days incubation periods

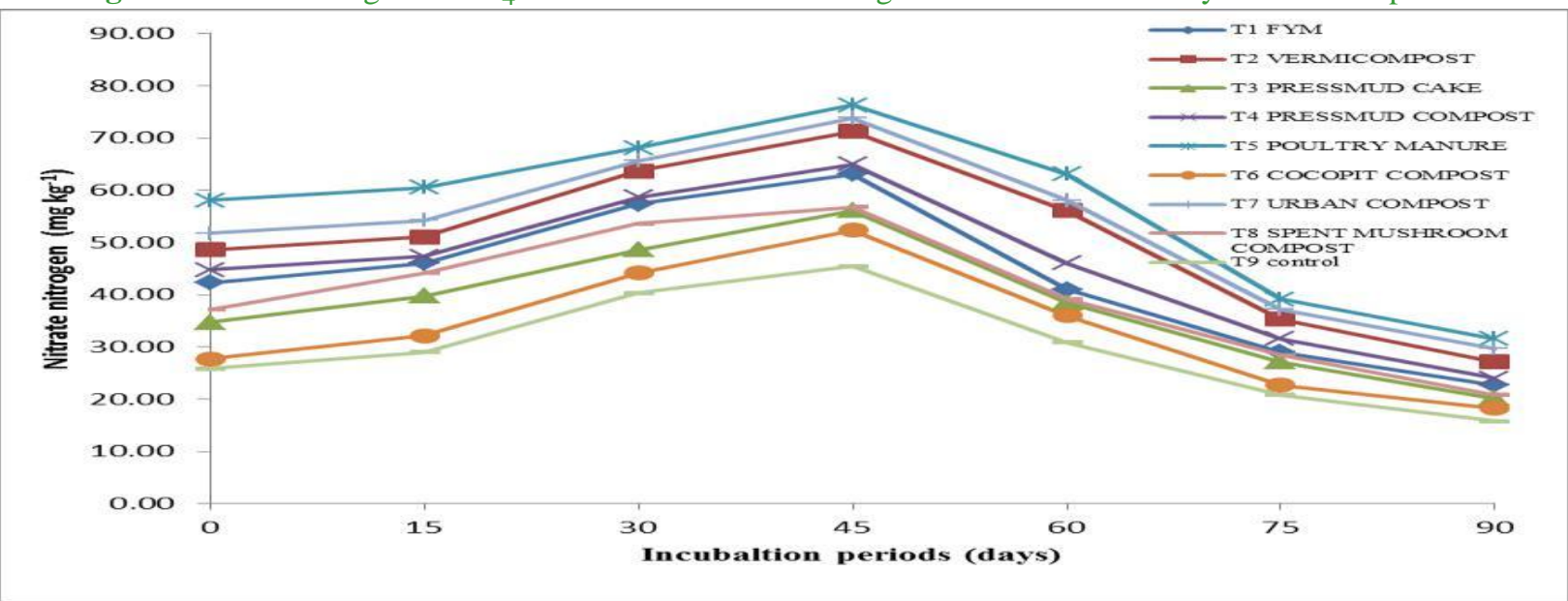

Fig.2 Periodical changes of $\mathrm{NO}_{3}-\mathrm{N}$ in soil from different organic manures for 90 days incubation periods

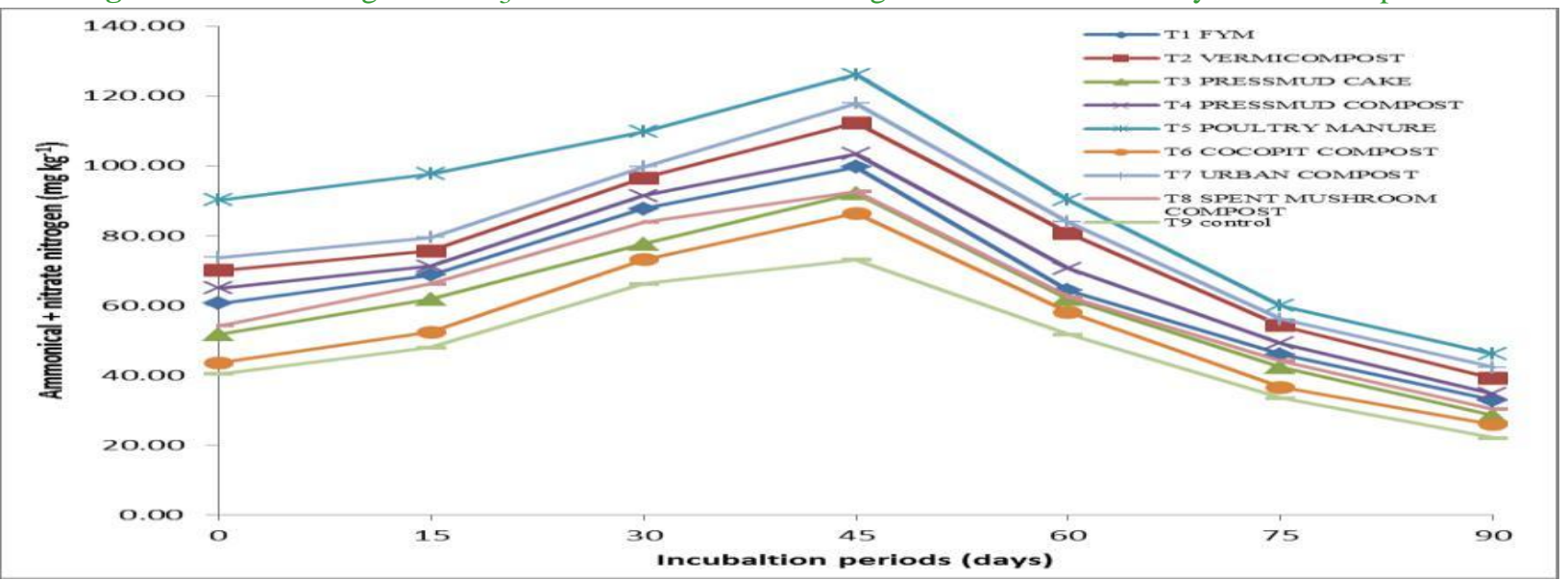

Fig.3 Periodical changes of $\mathrm{NH}_{4}-\mathrm{N}+\mathrm{NO}_{3}-\mathrm{N}$ in soil from different organic manures for 90 days incubation periods

\section{References}

Allison, L. E. and Moodie, C. D. (1965) Carbonates. In methods of soil analysis part 2, Chemical and Microbiological Properties Black, C.A (Ed) Wisconsin, U. S. A. 1379-1396.

Bremner, J. M. and Mulvaney, C. S.(1982) A 
procedure for estimation of total nitrogen. In Methods of Soil Analysis, Part-II, Page, A.L. (Ed.), II. (Ed.) Amer. Soc. Agron. Inc., Soil Science Society of America. Inc., Madison, Wisconsin, USA.pp:595.

Cabrera, M. L. and Kissel, D. E(1988) Evaluation of a method to predict nitrogen mineralized from soil organic matter under field conditions. Soil

Science Society of America Journal.52:1027-1031.

Chapman, H. D. and Pratt, P. F. (1961) Methods of analysis of soils, plants and waters. University of California Division of Agriculture Science, U.S.A. pp. 309.

Gorsuch, T. T. (1970). The destruction of organic matter.Pergamon press. Ltd., New York, 143-144.

Gupta, R. D., and Tripathi, B. R., (1986).Effect of organic materials on the carbon dioxide evolution and nitrogen mineralization in some soils of northwest Himalayas. Journal of the Indian Society of Soil Science34 (1):3842.

Jackson, M. L. (1973). Soil Chemical Analysis. Prentice Hall Private Limited, New Delhi. PP:498.

Keeney, D.R. and Nelson, D.W. (1982). Nitrogen-Inorganic forms. In: A.L. page (ed.) Methods of soil analysis. Chemical and microbiological propertied.America society of Agronomy, 9(2): 643-698. Knudsen, D., Peterson, G. A. and Pratt, P. F. (1982) Lithium, Sodium, Potassium. In Methods of Soil Analysis; Part-2, Page, A.L. (Ed.) Amer. Soc. Agron. Inc., Soil. Amer, Inc., Madison, Wisconsin, USA. pp. 225-245.

Lindsay, W. L. and Norvell, W. A. (1978).Development of a DTPA (diethylenetriaminepenta acetic acid) soil test of Zinc, iron, Manganese and Copper. Soil Sci. Soc. Am. J. 42 : 421murillo, J. M. (2011) Nitrogen mineralization of immatur municipal solid waste compost. Journal oF Plant Nutrition, 34:324-336.

Pedra, F., Polo, A., Carranca, C., Ribeiro, A. and Domingues, H.,(2011) Kinetics model fitted to nitrogen mineralization potential in soil amended with municipal compost and urban sewage sludge. Dynamic soil, Dynamic plant ,Global science books.

Richards, L. A. (1949) Pressure membrane apparatus construction and use. Agriculture engineering 28, 451-459

Stanford,G.and Smith, S.J.(1972) Nitrogen Mineralization Potentials of Soils. Soil science Society of America Journal, 36, 465-472.

Subbiah, B.V. and Asija, G.L. (1956).Rapid procedure for the estimation of available nitrogen in soil. Current Science, 25 : $259-260$.

\section{How to cite this article:}

Subhash Singh, Tamboli, B. D. Sonu Kumar and C.R. Palwe. 2020. Release Pattern of Ammonical and Nitrate Nitrogen in Inceptisol by the Use of Different Organic Manures. Int.J.Curr.Microbiol.App.Sci. 9(01): 1260-1266. doi: https://doi.org/10.20546/ijcmas.2020.901.139 